\title{
Climate Protection in Urban Transport-Six Scenario Studies in Germany: More Climate Protection, Fewer Carbon Dioxide Emissions, Less Car Traffic
}

\author{
Oscar Reutter $^{1}$ and Ulrike Reutter ${ }^{2}$ \\ 1. Wuppertal Institute for Climate, Environment and Energy, Wuppertal 42103, Germany \\ 2. School of Architecture and Civil Engineering, University of Wuppertal, Wuppertal 42285, Germany
}

\begin{abstract}
Six German scenario studies on urban passenger transport for Munich 2058, Wuppertal 2050, Eastern Ruhr Region 2030, Tuebingen 2030, Cologne 2020 and Hanover Region 2020 investigate the key question: With which strategies and on what kind of scale, is it possible to reduce the carbon dioxide emissions of urban passenger transport to accomplish the $2{ }^{\circ} \mathrm{C}$ climate protection goal with a consequently huge reduction of greenhouse gas emissions by $80 \%$ to $95 \%$ by 2050 in relation to the base year 1990 ? The scenarios show that the major challenge of a "climate-friendly city transport" can be achieved by appropriate measures (regarding direction and scale): in small and medium-sized cities, large cities, cities of over a million people, and metropolitan regions. The scenarios demonstrate the extent to which the considered measures contribute to the $\mathrm{CO}_{2}$ reduction, and which gap to the achievement of the goal remains if that which is currently regarded as realistic in practice is really implemented in future. Thus, they illustrate the conflict between that which is necessary for climate protection and that which is currently considered feasible in politics. The scenarios show that it is essential to act quickly and appropriately, and not hesitantly or without conviction.
\end{abstract}

Key words: Climate protection, $\mathrm{CO}_{2}$ reduction, urban transport, scenario studies, Germany.

\section{Introduction}

Urban transport planning in Germany was characterised for many years by the question of how to deal with growing motorized traffic as a consequence of economic, political, social and technological developments [1]. The question was ingrained in various models for urban planning (Fig. 1) [2, 3]. These reflected the changing attitudes towards means of transport and the urban environment. Prognoses and scenarios served to predict traffic levels, in order to develop concepts to cope with them. Forecasting scenarios were created to design strategies and measures, and, in multiple variations, reveal potential future conditions as a basis for political decision-making.

Corresponding author: Oscar Reutter, Dr.-Ing., professor, research fields: mobility and transport, urban and regional development and environmental quality, pilot projects and experiments for sustainable mobility and transport, sustainable urban development and co-operative planning.
In contrast, backcasting scenarios involve the determination of normative target values, e.g., with respect to the health, quality of life and mobility of the population, followed by the systematic search for appropriate paths to attain these values [4]. In relation to climate protection, such backcasting scenarios were first developed in Germany at the beginning of the 1990s, at federal level. More recently, further Germany-wide backcasting scenarios were developed within three studies: by Öko-Institut [5], by Öko-Institut and DLR-IVF [6], and in the FGSV (German Road and Transportation Research Association) [7].

Germany aims to reduce its total greenhouse gas emissions by $40 \%$ by 2020 , and by $80 \% \sim 95 \%$ by 2050 in relation to the baseline of 1990 (Fig. 2). And in fact, Germany is on its way to achieve these goals. But the transport sector misses these objectives so far. Within the transport sector, the carbon dioxide is the 


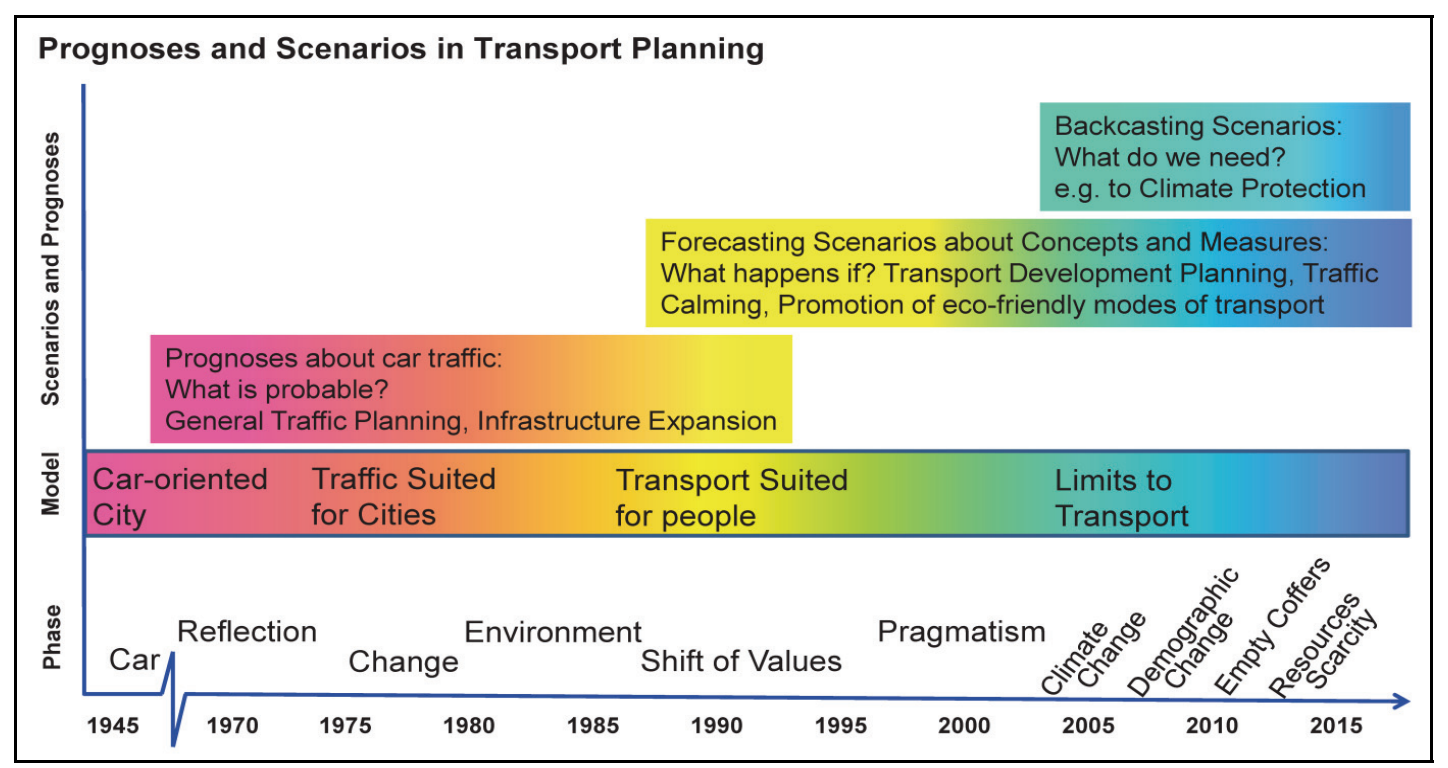

Fig. 1 Prognoses and scenarios in transport planning.

Source: Refs. [2, 3].

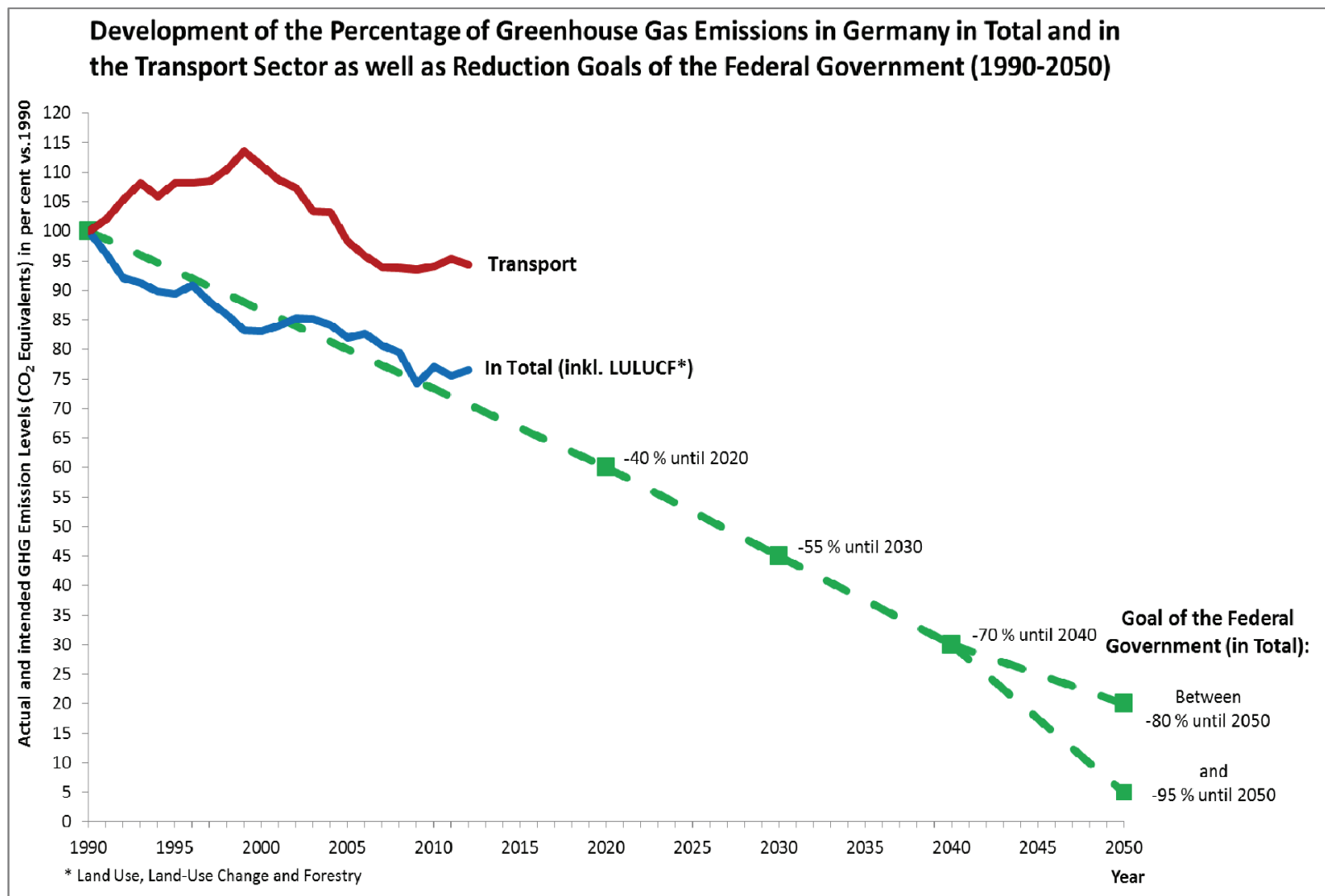

Fig. 2 Development of the percentage of greenhouse gas emissions in Germany in total and in the transport sector as well as reduction goals of the federal government (1990 2050).

Sources: Umweltbundesamt (Federal Environment Agency) (UBA) 2014: national trends charts for the German coverage of atmospheric emissions 1990 2012 (forthcoming; written advance information by Gniffken Patrick (UBA) of 06/03/2014);

Bundesministerium für Umwelt, Naturschutz, Bau und Reaktorsicherheit (Federal Ministry for Environment, Nature Conservation, Building and Nuclear Safety) (BMUB), as of 01/05/2013: climate protection policy in Germany (accessed March 5, 2014. http://www.bmub.bund.de/themen/klima-energie/klimaschutz/nationale-klimapolitik/). 
main important greenhouse gas. The transport sector, particularly road transport, causes about one-fifth of the total direct $\mathrm{CO}_{2}$ emissions of Germany and has likewise to contribute to the politically decided GHG (greenhouse gas) reduction goals of Germany. Thereto, it is necessary to think backwards from the $2{ }^{\circ} \mathrm{C}$ limit and the necessity of relevant reduced GHG emissions, respectively, $\mathrm{CO}_{2}$ emissions with adequate policies and measures regarding direction and scale. This is a challenging task for the national transport policy as well as the local transport policies of cities and regions.

Since 2006, the first climate protection scenarios at a specifically urban and metropolitan level have been developed. Six scenario studies for Munich 2058, Wuppertal 2050, Eastern Ruhr Region 2030, Tuebingen 2030, Cologne 2020 and Hanover Region 2020 investigate the central question: With which strategies and on what kind of scale, is it possible to reduce the carbon dioxide emissions of urban passenger traffic in such a way that this causative sector also contributes to the achievement of the climate protection goals?

\section{Munich 2058}

For Munich (1.3 million inhabitants, trend: growing population), two different scenarios for urban land-based passenger and freight traffic in the year 2058 (residence principle) were developed by the Wuppertal Institute in 2008, on behalf of Siemens AG, and compared with the 2008 benchmark case [8]. The aim was to show the technical feasibility of strategies for an extensive $\mathrm{CO}_{2}$ neutrality.

In passenger traffic, the purely technology-oriented action scenario "bridge" (what will happen if...?) takes as a starting point of the highly efficient traffic engineering (combustion engines, electromobility, biofuels) in motorized individual transport and public transport. As a result, the absolute $\mathrm{CO}_{2}$ emissions caused by transport will decline by $33 \%$ from an annual 1.1 million $t$ in 2008 to an annual 750,000 $t$ by
2058 in comparison to the 2008 benchmark case, declining by $42 \%$ if the total electricity used in traffic is produced on a renewable basis.

The more ambitious goal scenario "goal" (what do we need?), in addition to assuming the even more intensive application of technical improvements, makes optimistic assumptions about behavioural change, to demonstrate the path to an nearly $\mathrm{CO}_{2}$-free future. Noticeable effects of traffic avoidance (reduction of transport volume by $10 \%$ per capita) and a distinct modal shift from motorized private transport to the environmentally friendly modes of transport (walking, cycling, public transport) mean that, in 2058 , over $70 \%$ of all daily trips will be covered by the environmentally friendly modes of transport. This scenario also includes a substantially increased promotion of electric cars, thereby causing a reduction of absolute $\mathrm{CO}_{2}$ emissions in transport of $52 \%$ to an annual $534,000 \mathrm{t}$ in the timeframe 2008 to 2058 , or even of $69 \%$ if additional reduction effects were developed for electricity consumption in transport by using renewable energies and combined heat and power. In conclusion, the efforts required for the goal scenario "goal" appear challenging but viable.

\section{Wuppertal 2050}

For Wuppertal (350,000 inhabitants, trend: declining population), two goal scenarios (what do we need?) were developed in an internal research project at the Wuppertal Institute for urban passenger transport in 2050 (residence principle) [9]. The extent to which the passenger transport of Wuppertal citizens would have to contribute to climate protection was investigated using this backcasting approach. The model calculations show that the $\mathrm{CO}_{2}$ emissions of passenger transport in Wuppertal can be reduced by an absolute $85 \%$ by 2050 , or by $78 \%$ per capita, in comparison to the base year 1990, provided that:

(1) One per mille of passenger kilometres per year is saved through traffic avoidance; 
(2) With the modal shift as a central local politics field of action, a distinct modal shift from the car to the environmentally friendly modes of transport is achieved, meaning that the share of trips made by car is halved from $51 \%$ in 2002 to $26 \%$ in 2050 and the share of trips realised by environmentally friendly modes of transport increases from $49 \%$ in 2002 to $74 \%$ in 2050 ;

(3) In automotive engineering, the motor vehicle-specific $\mathrm{CO}_{2}$ emissions of the car and of public transport, is, primarily through EU and federal policy measures, reduced by $2 \%$ per year, twice as much as in the existing trend development;

(4) With a decline in population of over 100,000 inhabitants by 2050 , half of the associated conceivable $\mathrm{CO}_{2}$ reduction potential is actually realised.

In conclusion, the necessary efforts for the $-80 \%$ $\mathrm{CO}_{2}$ goal scenario seem ambitious but manageable. A $-95 \% \quad \mathrm{CO}_{2}$ goal scenario (1990 2050) would necessitate extreme steps which are difficult to imagine at present: Wuppertal would have to be developed as a car-free city in which urban traffic is exclusively conducted by the environmentally friendly modes of transport with a highly efficient public transport system.

\section{Eastern Ruhr Region 2030}

For the Eastern Ruhr Region (extended Dortmund City Region, 2.6 million inhabitants, trend: declining population), a scientific action scenario study was carried out by the Office of Spiekermann \& Wegener Urban and Regional Research for the European Union in 2006 [10]. Several action scenarios (what will happen if...?) for the land-based passenger traffic are elaborated therein for the year 2030 (residence principle) and compared with the 2005 benchmark case. With this, the long-term economic, social and environmental effects of possible fuel price increases and various policies and measures are evaluated; For the environmental effects, the development of $\mathrm{CO}_{2}$ emissions is also investigated.
Three variations are examined as conceivable future annual fuel price increases: moderate: $+1 \%$; strong: $+4 \%$ and extreme: $+7 \%$. With these three energy price scenarios, five different action scenarios are combined: a "do nothing scenario", a "business as usual scenario", a pure "technology investments scenario" (economical cars, alternative vehicles/fuels, public transport expansion and acceleration), a pure "demand regulation scenario" (raised petroleum tax, additional road tolls, more traffic calming, more carsharing, more telecommuting, polycentric or compact settlement structure planning and lower public transport tariffs), and an "integrated policies scenario" in which all measures are implemented simultaneously.

These action scenarios establish clear $\mathrm{CO}_{2}$ reduction potentials. Rising fuel prices substantially intensify the $\mathrm{CO}_{2}$ savings effects. The most pronounced reduction effect is shown in the integrated policies scenario. Here, the share of trips realised by public transport increases and the share of trips realised by car decreases. As a result, relative to the base year 2005, the daily $\mathrm{CO}_{2}$ emissions per capita caused by transport are reduced particularly sharply: by between $60 \%$ in the case of a moderate petrol price increase and $80 \%$ in the case of an extreme petrol price increase. This effect is primarily due to the measures concerning influence on demand. However, the authors point out that, due to the high fuel price increases, this extreme scenario would be associated with a severe decline in wealth and quality of life, particularly for households with low income in less central locations.

Nonetheless, these scenarios demonstrate that, in the Eastern Ruhr Region, considerable $\mathrm{CO}_{2}$ savings per capita in passenger traffic can be achieved through a transport policy oriented approach at metropolitan level. Fuel price increases, combined with transport-political measures, thus lead to serious changes in mobility behaviour and the traffic situation. 


\section{Tuebingen 2030}

For Tuebingen $(85,000$ inhabitants, trend: stable population), a "BAU (business as usual) scenario" and a "sustainability scenario" as a backcasting scenario (what do we need?) for urban passenger transport (residence principle) were developed for the year 2030 by the Institute for Mobility and Transport of the University of Kaiserslautern on behalf of the City of Tuebingen and published as the scientific report Mobilität Tübingen 2030 (Tuebingen Mobility 2030) $[11,12]$.

The BAU scenario expects that, despite increasing travel distances and more car traffic, the absolute $\mathrm{CO}_{2}$ emissions in urban passenger traffic will, on balance, decline by $25 \%$ by 2030 relative to the base year 2008 , through technical efficiency enhancements in motorized vehicles. The sustainability scenario is aimed at achieving an additional $25 \%$ reduction of $\mathrm{CO}_{2}$ through behavioural changes as the result of integrated city and transportation planning in Tuebingen. Therefore, the travel distances for Tuebingen inhabitants should be shortened by $10 \%$, and $10 \%$ of the transport share of car traffic should be transferred to the environmentally friendly modes of transport; An efficiency enhancement accelerated by supplementary municipal measures (user benefits, incentives and purchase advice) should lead to $40 \%$ less $\mathrm{CO}_{2}$ emissions per kilometers for the total vehicle fleet in Tuebingen.

In the sustainability scenario, 14 packages of measures in the action fields of settlement development, public transport and multimodality, urban space and traffic, and mobility management are developed in dialogue with an advisory body and in several workshops with local stakeholders. All packages of measures are described in profiles: goal, specific measures, benefits for traffic and urban planning, costs for the municipal household (investment costs and running costs in euro), estimation of the level of acceptance (from very low to very positive), expected $\mathrm{CO}_{2}$ reduction potential (in percentage), relevant stakeholders in the implementation and initial steps for the realisation. The effects on traffic and the resulting $\mathrm{CO}_{2}$ reduction potential of the packages of measures are evaluated using a computer model on transport simulation.

The model calculations show that, with the sustainability scenario, the absolute $\mathrm{CO}_{2}$ emissions in passenger traffic in Tuebingen can be roughly halved by 2030 in comparison to $2008(-52,4 \%)$. The Tuebingen local council selected the overall plan Tuebingen Mobility 2030 at the beginning of 2011 as the basis for further administrative action in Tuebingen. Since then, it has been implemented step by step.

\section{Cologne 2020}

For Cologne (1 million inhabitants, trend: growing population), based on a detailed traffic assessment for the year 2006 (territoriality principle, passenger and freight traffic, not including air traffic or transit traffic), two action scenarios (what will happen if...?) were developed in 2011 for the year 2020 by the Wuppertal Institute on behalf of the City of Cologne: a "reference scenario" and a "climate protection scenario", which consider the conceivable developments in population, traffic density and motor vehicle technology [13, 14]. The scenarios aim to show the $\mathrm{CO}_{2}$ reduction potential in transport, which can be opened by the City of Cologne. In the base year 2006, the $\mathrm{CO}_{2}$ emissions of the traffic in Cologne, excluding air and transit traffic, were an absolute $1,598.1 \mathrm{kt} / \mathrm{a}$, or respectively $1.6-\mathrm{t} \mathrm{CO}_{2}$ per capita annually.

The reference Scenario 2020 considers the $\mathrm{CO}_{2}$ reduction effect of all local climate protection measures in traffic which had taken effect by the end of 2006, as well as the $\mathrm{CO}_{2}$ reduction effect of the measures at $\mathrm{EU}$, national or federal state level. It sees the absolute $\mathrm{CO}_{2}$ emissions of the traffic in Cologne decrease by $19 \%$ in relation to 2006 and by $21 \%$ in relation to 1990 . This means that, in the reference scenario 2020, the $\mathrm{CO}_{2}$ emissions of the traffic in Cologne (excluding air and transit traffic) are an 
absolute $1,314.7 \mathrm{kt} / \mathrm{a}$ or respectively $1.3-\mathrm{t} \mathrm{CO}_{2}$ per capita annually.

The climate protection scenario 2020 also considers the $\mathrm{CO}_{2}$ reduction effect of a further 29 technical and non-technical reduction measures. These were developed within the framework of the climate protection concept in dialogue with local stakeholders, and recommended for implementation. They substantiate the fields of action of improved motor vehicle technology in new purchases, promotion of cycling, public transport development, organisation of economic trade and public relations. The $\mathrm{CO}_{2}$ reduction effects were assessed quantitatively and the implementation costs (financial, organisational and time costs) were estimated qualitatively (high-medium-low). In addition, the period required for the development of the $\mathrm{CO}_{2}$ reduction effects was estimated (short, medium or long term).

With the 29 additional climate protection measures, the absolute $\mathrm{CO}_{2}$ emissions of the traffic in Cologne, which can be directly influenced by the policy of the City of Cologne, decrease until 2020 by $25 \%$ in relation to 2006 and by $28 \%$ in relation to 1990 . This means that Cologne's commitment in the transport sector, made as a member of the Klimabündnis (Climate Alliance) of cities (to reduce the city's $\mathrm{CO}_{2}$ emissions by $50 \%$ by 2030 and by $38 \%$ by 2020 ), cannot be fully achieved. In the climate protection scenario 2020, the $\mathrm{CO}_{2}$ emissions of the traffic in Cologne (excluding air and transit traffic) are an absolute $1,204.3 \mathrm{kt} / \mathrm{a}$ or respectively $1.2-\mathrm{t} \mathrm{CO}_{2}$ per capita annually, i.e., a saving of $0.1-\mathrm{t} \mathrm{CO}_{2}$ per inhabitant per year compared to the reference scenario 2020, or a saving of 0.4-t $\mathrm{CO}_{2}$ per inhabitant per year compared to the base year 2006 .

The Cologne 2020 climate protection scenario shows that the suggested measures which can be realised by the city of Cologne can contribute considerably to the $\mathrm{CO}_{2}$ reduction, but they alone are not adequate to achieve the climate protection goals in the urban transport sector.

\section{Hanover Region 2020}

For the Hanover Region (1.1 million inhabitants, of which 520,000 inhabitants in the federal state capital Hanover, trend: stable population), the Pro-climate TDP (Transport Development Plan) was created $[15,16]$. The expert research for this was carried out by the Offices of Gertz-Gutsche-Rümenapp and Proloco on behalf of the Hanover Region. It was approved by the regional assembly on September 27, 2011. ${ }^{1}$

In the Pro-climate TDP, the regional initial situation in 2010 was analysed firstly: From 1990 until 2010, the $\mathrm{CO}_{2}$ emissions caused by traffic had increased from 2.0 to 2.3 million $t$ per year $(+11 \%)$. Consequently, the $\mathrm{CO}_{2}$ emissions caused by traffic must be reduced by $51 \%$ between 2010 and 2020, in order to still achieve the regional policy reduction goal of $40 \%$ fewer $\mathrm{CO}_{2}$ emissions in the period 1990 to 2020. An overall view of external effects as an assessment of trends 2010 2020 (vehicle efficiency, demography, petrol price and long distance traffic, especially lorries), on which the Hanover Region has no substantial influence, indicates that only a minimal reduction of the $\mathrm{CO}_{2}$ emissions caused by traffic can be expected $(-1 \%)$. The $\mathrm{CO}_{2}$ reduction goals are thus not achieved through these external effects only.

For this reason, for the passenger transport in the Hanover Region for the year 2020 in a goal scenario (what do we need?), the $\mathrm{CO}_{2}$ savings potential for 11 packages of measures in four fields of action (settlement development/local mobility; public transport; traffic management, road infrastructure and parking; mobility management) were evaluated with a traffic simulation model (residence principle). The

\footnotetext{
${ }^{1}$ The Pro-climate Transport Development Plan of the Hanover Region was awarded the Deutscher Verkehrsplanungspreis (German Transport Planning Prize) 2012, which was presented by the Vereinigung für SRL (Stadt-, Regional- und Landesplanung) (German Association for City and Regional Planning) and the Verkehrsclub Deutschland (VCD: a German transport association with a focus on ecology), for the best project in Germany on the topic "transport and climate protection".
} 
catalogue of measures contains projects which can be realised by 2020. It is guided by the three-stage transport strategy: avoid traffic, modal shift and improve motorized traffic.

According to the results of the simulation calculations, there is a modal shift in traffic volume (all trips, weekdays) from 2002 to 2020: 11\% of all the trips would be shifted. The share of trips made by car decreases from $51 \%$ to $40 \%$ and the share of trips made by environmentally friendly modes of transport increases from $49 \%$ to $60 \%$. The measures open a theoretical absolute savings potential of $44 \% \mathrm{CO}_{2}$ emissions in regional passenger traffic by 2020, in relation to 1990 . An absolute $\mathrm{CO}_{2}$ reduction of $35 \%$ by 2020 in regional passenger traffic, in relation to 1990, is considered as true feasible savings potential. This means that the intended goal of an absolute $\mathrm{CO}_{2}$ reduction of $40 \%$ by 2020 in relation to 1990 is not completely achieved.

In addition, so-called "visionary ideas" for new innovative forms of automobility were researched: area-wide carsharing, promotion of electromobility, privileging low $\mathrm{CO}_{2}$ emission cars, solely urban redevelopment, consequent parking management, introduction of congestion charges for the city and region. In this way, considerable further contributions would be made to $\mathrm{CO}_{2}$ reduction. Thus far, however, these approaches have been assessed unrealistic.

Following the political decision on the Pro-climate TDP, the administration was commissioned to implement the measures step by step. Since then, initial implementation projects have been realised: the priorities concern cycling traffic, the changeover of the city's bus fleet to hybrid technology, the expansion of the regional rail service, and an offensive in the field of mobility management.

\section{Conclusions}

The six scenario studies show that it is possible for urban and/or metropolitan transportation concepts to be specifically guided by the politically desirable climate protection goal: the $2{ }^{\circ} \mathrm{C}$ goal with a consequently huge reduction of greenhouse gas emissions by $80 \%$ to $95 \%$ by 2050 in relation to the base year 1990 [17]. The transport sector, too, which is responsible for around a fifth of $\mathrm{CO}_{2}$ emissions in Germany, the most quantitatively significant greenhouse gas, can and should contribute to an effective climate protection. The scenarios show, with appropriate direction and adequate scale, that the major challenge of "climate-friendly city traffic" can be achieved: in small and medium-sized cities, large cities, cities of over a million people, and metropolitan regions (Table 1 ).

The particular focus of the concepts is on passenger transportation; Freight transportation is additionally addressed in two studies (Cologne 2020, Munich 2058). All concepts use the scenario technique to formulate "If A, then B" statements for planning and politics. The concepts with a short time horizon of 10 15 years (Cologne 2020, Hanover Region 2020) focus on implementation in their description of possible climate protection measures; The concepts with a long-term time horizon of 40 50 years (Munich 2058, Wuppertal 2050) outline the principal suitable climate protection strategies; The concepts with a medium-term time horizon (Tuebingen 2030, Eastern Ruhr Region 2030) use a combined approach.

The scenario assumptions concerning the achievable $\mathrm{CO}_{2}$ reduction effect of the strategies and measures are based on expert assessments and literature reviews of empirical experiences from other cities. Inexactness is accepted due to a lack of better alternatives. The scenario studies use quantitative calculation models to evaluate the effects of various assumptions. For the most part, scenarios in growing or shrinking cities or regions consider not only the development of the transport-caused annual absolute $\mathrm{CO}_{2}$ emissions, but also the $\mathrm{CO}_{2}$ emissions per capita.

All concepts follow the traffic planning principles: "avoid-shift-improve". Through a combined implementation of the generally well-known measures, 
Table 1 Scenarios for climate-friendly transport in selected German cities and regions [8-11, 13, 15].

\begin{tabular}{|c|c|c|c|c|c|c|}
\hline Scenario & Munich 2058 & Wuppertal 2050 & Tuebingen 2030 & Ruhr District-East 2030 & Cologne 2020 & Hanover 2020 \\
\hline Type of city & $\begin{array}{l}\text { City of population over a } \\
\text { million, growing } \\
\text { (population: } 1.3 \text { million) }\end{array}$ & $\begin{array}{l}\text { Large town, } \\
\text { shrinking } \\
\text { (population: } \\
350,000 \text { ) }\end{array}$ & $\begin{array}{l}\text { Medium-sized town, } \\
\text { stable } \\
\text { (population: 85,000) }\end{array}$ & $\begin{array}{l}\text { Region of over a million, } \\
\text { shrinking } \\
\text { (population: } 2.6 \text { million) }\end{array}$ & $\begin{array}{l}\text { City of a million, } \\
\text { growing } \\
\text { (population: } 1 \text { million) }\end{array}$ & $\begin{array}{l}\text { Region of over a million, } \\
\text { stable } \\
\text { (population: } 1.1 \text { million) }\end{array}$ \\
\hline $\begin{array}{l}\text { Main scenario } \\
\text { Technology and } \\
\text { behaviour }\end{array}$ & $\begin{array}{l}\text { Goal scenario: } \\
\text { "goal": } \\
\text { backcasting approach: What } \\
\text { do we need? }\end{array}$ & \begin{tabular}{|l|} 
Goal scenario: \\
"80\% $\mathrm{CO}_{2}$ \\
reduction goal": \\
backcasting \\
approach: What do \\
we need? \\
\end{tabular} & $\begin{array}{l}\text { Goal scenario: } \\
\text { "sustainability: } 50 \% \\
\mathrm{CO}_{2} \text { reduction goal": } \\
\text { backcasting approach: } \\
\text { What do we need? }\end{array}$ & $\begin{array}{l}\text { Action scenario: } \\
\text { "integrative": } \\
\text { forecasting approach: } \\
\text { What happens if...? }\end{array}$ & $\begin{array}{l}\text { Action scenario: } \\
\text { "climate protection": } \\
\text { forecasting approach: } \\
\text { What happens if...? }\end{array}$ & $\begin{array}{l}\text { Goal scenario: } \\
\text { "pro-climate } 40 \% \mathrm{CO}_{2} \\
\text { reduction goal": } \\
\text { backcasting approach: What } \\
\text { do we need? }\end{array}$ \\
\hline $\begin{array}{l}\text { Sub-scenarios } \\
\text { for comparison }\end{array}$ & Action scenario "bridge" & $\begin{array}{l}\text { Goal scenario } \\
\text { "95\% } \mathrm{CO}_{2} \\
\text { reduction goal" }\end{array}$ & $\begin{array}{l}\text { Business as usual } \\
\text { scenario }\end{array}$ & $\begin{array}{l}\text { Action scenarios: } \\
\text { "do nothing": } \\
\text { business as usual; } \\
\text { technology investments; } \\
\text { demand regulation } \\
\end{array}$ & Reference scenario & $\begin{array}{l}\text { Basic situation; } \\
\text { External effects; } \\
\text { Visionary ideas }\end{array}$ \\
\hline Type of transport & $\begin{array}{l}\text { Passenger and freight transport } \\
\text { (land-based) }\end{array}$ & $\begin{array}{l}\text { Passenger transport } \\
\text { (land-based) }\end{array}$ & $\begin{array}{l}\text { Passenger transport } \\
\text { (land-based) }\end{array}$ & $\begin{array}{l}\text { Passenger transport } \\
\text { (land-based) }\end{array}$ & $\begin{array}{l}\text { Passenger and freight } \\
\text { transport (land-based); } \\
\text { Excluding air traffic; } \\
\text { Excluding transit traffic }\end{array}$ & $\begin{array}{l}\text { Passenger transport } \\
\text { (land-based) }\end{array}$ \\
\hline \multicolumn{7}{|c|}{ Assumptions of the main scenarios (selection) } \\
\hline Fuel price trend & - & - & - & $\begin{array}{l}\text { Price increase variations } \\
\text { per year: } \\
+1 \%,+4 \%,+7 \%\end{array}$ & - & \multirow{3}{*}{$\begin{array}{l}\text { Demography and long } \\
\text { distance traffic almost } \\
\text { entirely offset } \mathrm{CO}_{2} \text { savings } \\
\text { effects through vehicle } \\
\text { efficiency and fuel price } \\
\text { increase; } \\
\text { Balance: }-1 \% \mathrm{CO}_{2} \\
\text { emissions in } 2020 \\
\text { compared with } 2010\end{array}$} \\
\hline $\begin{array}{l}\text { Population } \\
\text { development and } \\
\mathrm{CO}_{2} \\
\end{array}$ & Increase: rising $\mathrm{CO}_{2}$ emissions & $\begin{array}{l}\text { Decline: decreasing } \\
\mathrm{CO}_{2} \text { emissions }\end{array}$ & Constant & $\begin{array}{l}\text { Decline; evaluated per } \\
\text { capita }\end{array}$ & $\begin{array}{l}\text { Increase: rising } \mathrm{CO}_{2} \\
\text { emissions }\end{array}$ & \\
\hline $\begin{array}{l}\text { Improvement in } \\
\text { technology }\end{array}$ & $\begin{array}{l}\text { Significant efficiency } \\
\text { enhancements and } \\
\text { electrification in public and } \\
\text { motorized private transport; } \\
\text { Biofuels: further reduction } \\
\text { through renewable electricity } \\
\text { generation and CHP } \\
\text { (combined heat and power) }\end{array}$ & $\begin{array}{l}\mathrm{CO}_{2} \text { emissions of } \\
\text { cars and public } \\
\text { transport are } \\
\text { reduced by two } \\
\text { thirds primarily } \\
\text { through EU and } \\
\text { federal policy } \\
(2050 \text { versus } 1990)\end{array}$ & $\begin{array}{l}\text { Communal additional } \\
\text { efforts for efficiency } \\
\text { enhancement increase } \\
\text { the efficiency } \\
\text { enhancement in the } \\
\text { BAU scenario from } \\
-35 \% \text { to }-40 \% \mathrm{CO}_{2} \\
\text { emissions per } \\
\text { kilometers } \\
\end{array}$ & $\begin{array}{l}\text { Eco-friendly vehicles and } \\
\text { alternative fuels }\end{array}$ & $\begin{array}{l}\text { Improved motor vehicle } \\
\text { technology in new } \\
\text { purchases }\end{array}$ & \\
\hline
\end{tabular}


(Table 1 continued)

\begin{tabular}{|c|c|c|c|c|c|c|}
\hline Scenario & Munich 2058 & Wuppertal 2050 & Tuebingen 2030 & Ruhr District-East 2030 & Cologne 2020 & Hanover 2020 \\
\hline Traffic avoidance & $\begin{array}{l}10 \% \text { fewer passenger } \\
\text { kilometres per capita } 2058 \\
\text { versus } 2008\end{array}$ & \begin{tabular}{|l|}
1 per mille \\
passenger \\
kilometres saved \\
per year
\end{tabular} & $\begin{array}{l}10 \% \text { fewer passenger } \\
\text { kilometres } 2030 \text { versus } \\
2008\end{array}$ & \multirow[b]{2}{*}{$\begin{array}{l}\text { Raised fuel tax, } \\
\text { additional road tolls, } \\
\text { more telecommuting, } \\
\text { polycentric or compact } \\
\text { settlement structure } \\
\text { planning, public transport } \\
\text { expansion and } \\
\text { acceleration, lower } \\
\text { public transport tariffs, } \\
\text { more traffic calming, } \\
\text { more carsharing }\end{array}$} & \multirow[b]{2}{*}{$\begin{array}{l}29 \text { technical and } \\
\text { non-technical reduction } \\
\text { measures in the fields of } \\
\text { action: promotion of } \\
\text { cycling; public transport } \\
\text { development; } \\
\text { organisation of economy } \\
\text { transport; public relations }\end{array}$} & \multirow{2}{*}{$\begin{array}{l}11 \text { packages of measures in } \\
\text { four fields of action: } \\
\text { settlement } \\
\text { development/local mobility; } \\
\text { public transport; traffic } \\
\text { management, road } \\
\text { infrastructure and parking; } \\
\text { mobility management } \\
\text { from } 2002 \text { to } 2020 \text { : } \\
\text { environmentally friendly } \\
\text { modes of transport: from } \\
49 \% \text { to } 60 \% \text {; } \\
\text { Motorized private transport } \\
\text { from } 51 \% \text { to } 40 \%\end{array}$} \\
\hline $\begin{array}{l}\text { Redistribution of } \\
\text { traffic } \\
\text { (traffic share) }\end{array}$ & $\begin{array}{l}\text { 2058: over } 70 \% \text { of daily trips } \\
\text { by the environmentally } \\
\text { friendly modes of transport }\end{array}$ & $\begin{array}{l}\text { From } 2002 \text { to } 2050 \text { : } \\
\text { walking: } \\
\text { from } 32 \% \text { to } 32 \% \\
\text { bicycle: } \\
\text { from } 1 \% \text { to } 10 \% \\
\text { public transport: } \\
\text { from } 16 \% \text { to } 32 \% \\
\text { motorized private } \\
\text { transport: } \\
\text { from } 51 \% \text { to } 26 \%\end{array}$ & $\begin{array}{l}\text { From } 2008 \text { to } 2030: \\
10 \% \text { motorized private } \\
\text { transport share } \\
\text { transferred to the } \\
\text { environmentally } \\
\text { friendly modes of } \\
\text { transport }\end{array}$ & & & \\
\hline \multicolumn{7}{|c|}{ Results of the main scenarios } \\
\hline $\begin{array}{l}\mathrm{CO}_{2} \text { emissions } \\
\text { absolute }\end{array}$ & \begin{tabular}{|l}
$-69 \%$ \\
$(2058$ versus 2008)
\end{tabular} & \begin{tabular}{|l|}
$-85 \%$ \\
$(2050$ versus 1990$)$
\end{tabular} & \begin{tabular}{|l}
$-52.4 \%$ \\
$(2030$ versus 2008)
\end{tabular} & 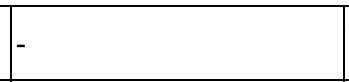 & \begin{tabular}{|l}
$-25 \%$ \\
$(2020$ versus 2006$)$
\end{tabular} & $\begin{array}{l}-35 \% \\
(2020 \text { versus } 1990)\end{array}$ \\
\hline $\begin{array}{l}\mathrm{CO}_{2} \text { emissions per } \\
\text { capita }\end{array}$ & t & $\mid$\begin{tabular}{|l}
$-78 \%$ \\
$(2050$ versus 1990$)$
\end{tabular} & $t$ & $\begin{array}{l}\text { Between }-61 \% \text { and } \\
-79 \% \\
(2030 \text { versus } 2005), \\
\text { depending on fuel price } \\
\text { increase }\end{array}$ & $\begin{array}{l}-0.4 \mathrm{tCO}_{2} \text { per year } \\
(2020 \text { versus 2006) }\end{array}$ & 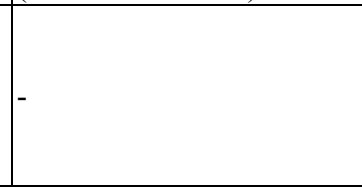 \\
\hline
\end{tabular}




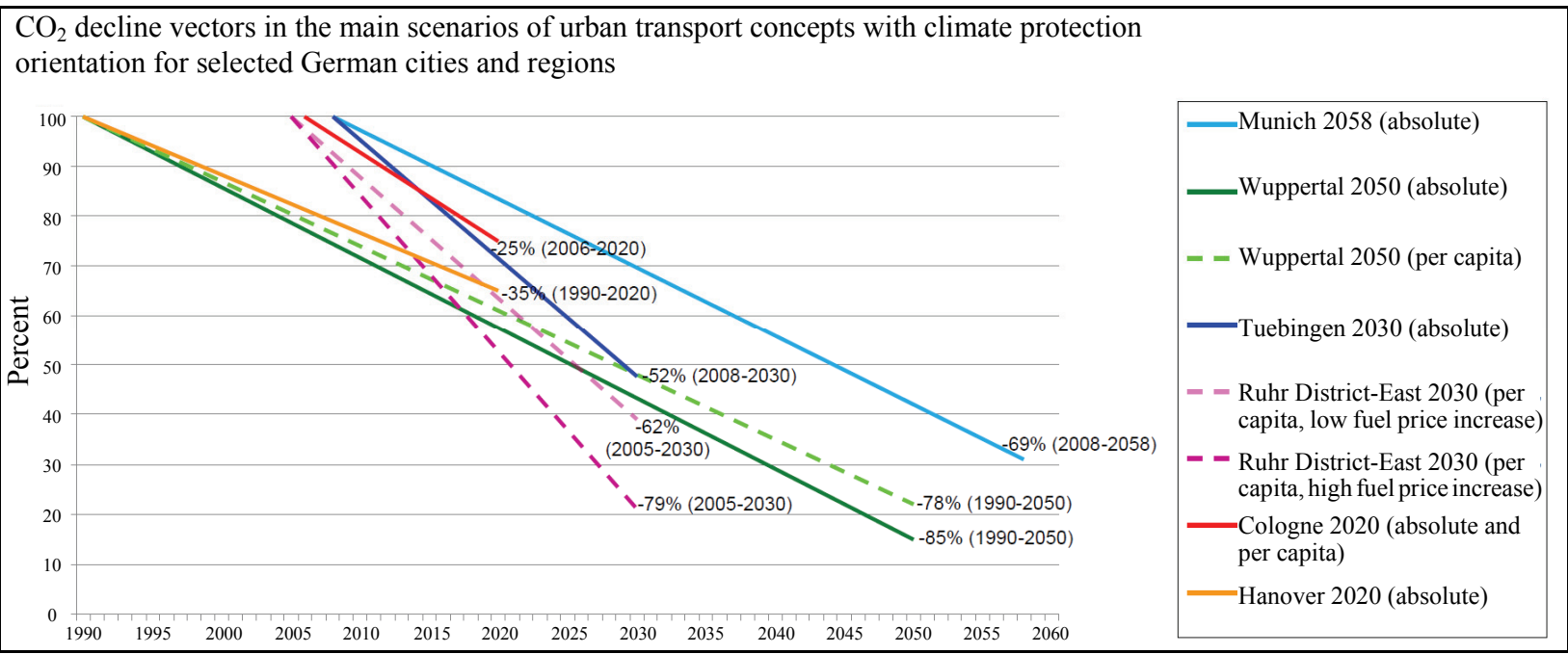

Fig. 3 Decline vectors in the main scenarios $[8-11,13,15]$.

substantial $\mathrm{CO}_{2}$ emission reductions in urban passenger traffic can be achieved.

All concepts take significant technical efficiency enhancements in motor vehicles as their starting point, which are primarily initiated by the European Union and German federal policy and partially reinforced by local strategies. In addition, all concepts assume that measures for changing transportation behaviour are necessary and possible. Technology and behaviour should therefore work together.

Traffic avoidance through the development of a city of short routes and, more importantly, modal shift are considered important strategies for urban and regional action. Through consequent push $\&$ pull measures, a modal shift from motorised individual transport to the environmentally friendly modes of transport means of transport, should be achieved. An active local and/or regional modal shift policy is expected to affect substantial contributions to the reduction of $\mathrm{CO}_{2}$ emissions of passenger traffic. For this to happen, considerable changes in mobility behaviour and in traffic are necessary. At the same time, the scenarios also reveal possible undesirable economic and social side effects, particularly for households with low income. It is important that this is considered and used for compromise in the concrete discussion of measures.
In conclusion, all scenarios demonstrate the extent to which the considered measures contribute to the $\mathrm{CO}_{2}$ reduction (Fig. 3), and which gap to the achievement of the goal remains if that which is currently regarded as realistic in practice is really implemented in future.

Overall, the transport scenarios show that it is essential to act quickly and appropriately, and not hesitantly or without conviction. They act as a stimulus for an intensive discussion in theory and practice on a consequent urban transport, which is guided by climate protection and socially acceptable, too. They also illustrate the field of conflict between that which is necessary for climate protection and that which is currently considered feasible in politics.

\section{References}

[1] Reutter, O., and Reutter, U. 2015. "Klimaschutz im Stadtverkehr-Sechs Szenariostudien in Deutschland." Revised English version. RaumPlanung (Spatial Planning) Journal 173 (2): 8-15. (in German)

[2] Schmucki, B. 2001. Der Traum vom Verkehrsfluss. Städtische Verkehrsplanung seit 1945 im Deutsch-Deutschen Vergleich (The Traffic Flow Dream. Urban Traffic Planning since 1945 in German-German Comparison). Frankfurt: Campus Verlag. (in German)

[3] Steierwald, G., Künne, H. D., and Vogt, W. 2005. Stadtverkehrsplanung-Grundlagen, Methoden, Ziele (City Traffic Planning-Principles, Methods, Goals). Berlin, Heidelberg: Springer. (in German) 
[4] Vogt, W. 2005. "Prognosen und Szenarien (Prognoses and Scenarios)." In Stadtverkehrsplanung-Grundlagen, Methoden, Ziele (City Traffic Planning-Principles, Methods, Goals), edited by Steierwald, G., Künne, H. D., and Vogt, W. Berlin, Heidelberg: Springer. (in German)

[5] Oeko-Institut (Institute for Applied Ecology) and Prognos AG. 2009. Modell Deutschland-Klimaschutz bis 2050: Vom Ziel her denken (Germany Model-Climate Protection until 2050: Thinking Backwards from the Goal). Final report produced on behalf of WWF (World Wide Fund for Nature) Germany. (in German)

[6] Oeko-Institut (Institute for Applied Ecology), German Aerospace Center and Institute for Systems and Innovation Research. 2013. Weiterentwicklung des Analyseinstruments Renewbility-RENEWBILITY II-Szenario für einen Anspruchsvollen Klimaschutzbeitrag des Verkehrs (Further Development of the Analytical Tool Renewbility-RENEWBILITY II-Scenario for an Ambitious Contribution of the Transport Sector to Climate Protection). Dessau-Roßlau: German Federal Environment Agency. (in German)

[7] FGSV (German Road and Transportation Research Association) Cross-Section Committee 7 on Post-Fossil Fuels Traffic. 2015. Übergänge in den Postfossilen Verkehr-Zusammenfassung der Ergebnisse: Notwendigkeiten, Entwicklungstrends und pfade (Transitions in Post-Fossil Fuels Traffic-Summary of the Results: Requirements, Trends and Development Paths). Cologne: FGSV-Verlag. (in German)

[8] Wuppertal Institute. 2009. Sustainable Urban Infrastructure: Munich Edition-Paths toward a Carbon-Free Future. Munich: Siemens AG.

[9] Reutter, O. 2011. "Klimaschutz als Herausforderung für einen Zukunftsfähigen Stadtverkehr-Strategien und Größenordnungen zur Minderung der Kohlendioxidemissionen (Climate Protection as a Challenge for Sustainable Urban Transport-Strategies and Scale for the Reduction of Carbon Dioxide Emissions)." In Handbuch der Kommunalen Verkehrsplanung (Handbook of Communal Traffic Planning), edited by Bracher, T., Haag, M., Holzapfel, H., Kiepe, F., Lehmbrock, M., and Reutter, U. Berlin: VDE Verlag. (in German)

[10] Fiorello, D., Huismans, G., López, E., Marques, C., Steenberghen, T., and Wegener, M., et al. 2006.
Transport Strategies under the Scarcity of Energy Supply. STEPs (Scenarios for the Transport System and Energy Supply and Their Potential Effects) final report. The Hague: Buck Consultants International.

[11] Haag, M., Henkel, A., Hahn, O., and Hoffmann, A. 2011. Mobilitaet 2030 Tuebingen: Abschlussbericht der Pilotphase im Projekt "Nachhaltiger Stadtverkehr Tübingen" (Mobility 2030 Tuebingen-Final Report on the Pilot Phase in the Project "Sustainable Urban Traffic in Tuebingen"). Tuebingen: Stadt Tuebingen Online. (in German)

[12] Von Winning, T., Henkel, A., and Schott, B. 2012. "Klimaschutzkonzept Tuebingen (Climate Protection Concept Tuebingen)." In Handbuch der Kommunalen Verkehrsplanung (Handbook of Communal Traffic Planning), edited by Bracher, T., Haag, M., Holzapfel, H., Kiepe, F., Lehmbrock, M., and Reutter, U. Berlin: VDE Verlag. (in German)

[13] Wuppertal Institute. 2011. Klimaschutzkonzept für die Stadt Köln-Teilbereich Verkehr-im Auftrag der Stadt Köln (Climate Protection Concept for the City of Cologne-Transport Sector-on Behalf of the City of Cologne). Wuppertal: Wuppertal Institute. (in German)

[14] Böhler-Baedecker, S., Jansen, U., and Müller, M. 2012. "Konzepte für $\mathrm{CO}_{2}$-arme Mobilität in der Stadt (Concepts for a Low-Carbon Mobility in the City)." RaumPlanung (Spatial Planning) Journal 162: 24-7.

[15] Hanover Region. 2011. Verkehrsentwicklungsplan pro Klima (VEP pro Klima) (Pro-climate Transport Development Plan (Pro-climate TDP)). Hanover: Hanover Region. (in German)

[16] Geschwinder, K., Göbler, T., Bohnet, M., and Walther, C. 2013. "Strategien für Klimafreundliche Mobilität: Der Verkehrsentwicklungsplan pro Klima der Region Hannover (Strategies for Climate-Friendly Mobility: The Pro-climate Transport Development Plan of the Hanover Region)." In Handbuch der Kommunalen Verkehrsplanung (Handbook of Communal Traffic Planning), edited by Bracher, T., Haag, M., Holzapfel, H., Kiepe, F., Lehmbrock, M., and Reutter, U. Berlin: VDE Verlag. (in German)

[17] BMUB (German Federal Ministry for the Environment, Nature Conservation, Building and Nuclear Safety). 2013. Klimaschutzpolitik in Deutschland (Climate Protection Policy in Germany). Bonn: BMUB. (in German) 